\title{
New species of Baltic amber soldier beetles (Insecta: Coleoptera: Cantharidae)
}

\section{Новые виды мягкотелок (Insecta: Coleoptera: Cantharidae) из БаАтийского янтаря}

\author{
Sergey V. Kazantsev \\ C.В. Казанцев
}

Insect Centre, Donetskaya 13-326, Moscow 109651, Russia. E-mail: kazantss@mail.ru Инсект-центр, ул. Донецкая 13-326, Москва 109651, Россия.

KEY WORDS: Coleoptera, Cantharidae, new species, Baltic amber, palaeoentomology, Middle Eocene.

КЛЮЧЕВЫЕ СЛОВА: Coleoptera, Cantharidae, новые виды, балтийский янтарь, палеоэнтомология, средний эоцен.

ABSTRACT. Two new species, Lycocerus crassepunctatus and Malthodes aliger spp.n., are described from the Baltic amber. So the number of Baltic amber species in Lycocerus Gorham, 1889 and Malthodes Kiesenwetter, 1852 has grown, respectively, to five and twenty one.

РЕЗЮМЕ. Из Балтийского янтаря описывается два новых вида, Lycocerus crassepunctatus и Malthodes aliger spp.n. Число известных из балтийского янтаря видов Lycocerus Gorham, 1889 and Malthodes Kiesenwetter, 1852 тем самым увеличивается, соответственно, до пяти и двадцати одного.

\section{Introduction}

Soldier beetles inclusions are fairly common in Baltic amber, and the first fossil taxon of this family was described from Baltic amber back in the XIX century [Schaufuss, 1892]. Later on records were made of a number of extant genera [Helm, 1896; Zang, 1905; Klebs, 1910], however, it was not until the 1960s that a second Baltic amber cantharid taxon was described [Yablokov-Khnozoryan, 1960]. It was followed by a number of others and now over seventy species of Cantharidae from three subfamilies, Cantharinae, Silinae and Malthininae, are known from Baltic amber.

A further study of Baltic amber inclusions, this time from the Museum of Amber Inclusions (Gdanisk, Poland), allows adding two new species from the genera Lycocerus Gorham, 1889 (Cantharinae) and Malthodes Kiesenwetter, 1852 (Malthininae). Lycocerus is known by several hundred species in the Oriental and East Palaearctic realms and Malthodes, the most speciesrich genus in Cantharidae, is distributed in all of the
Holarctic, with some representatives penetrating into the Oriental region [Delkeskamp, 1977; Kazantsev, Brancucci, 2007]; and in both of them Baltic amber species have been registered, 4 species in Lycocerus [Kazantsev, 2020] and 20 species in Malthodes [Parisi, Fanti, 2020]. Description of these two additional new species is presented below.

\section{Material and Methods}

Baltic amber is referred to the Middle Eocene, $c a$. 40-50 mya [e.g., Gaigalas, Halas, 2009], and can be found along the Baltic Sea coast. The studied specimens come from the Yantarny mine (Kaliningrad Region, Russia). The specimens had been cut and polished, and then examined with a MSP-1 zoom stereoscopic dissecting microscope with $\times 8-\times 80$ magnification range. Photographs were taken with Canon EOS 70D camera and Canon MP-E $65 \mathrm{~mm}$ macro lens.

The following acronyms are used in the paper: JDC - Jonas Damzen collection (Vilnius, Lithuania); MAIG - Museum of Amber Inclusions (Gdańsk, Poland).

\section{Taxonomy}

Cantharidae Imhoff, 1856 (1815)

Cantharinae Imhoff, 1856 (1815)

Cantharini Imhoff, 1856 (1815)

Lycocerus Gorham, 1889

Type species: Lycocerus serricornis Gorham, 1889 [= Omalisus maculicollis Hope, 1831], subsequent designation by Delkeskamp, 1977

How to cite this article: Kazantsev S.V. 2021. New species of Baltic amber soldier beetles (Insecta: Coleoptera: Cantharidae) // Russian Entomol. J. Vol.30. No.2. P.153-158. doi: 10.15298/rusentj.30.2.08 


\section{Lycocerus crassepunctatus Kazantsev sp.n.} Figs $1-4$.

MATERIAL: Holotype, $\sigma^{7}$, specimen No. MAIG 6699, Baltic amber, Middle Eocene, Gdansk Gulf Baltic amber (Kaliningrad Oblast, Russia) (ex. coll. Jonas Damzen, Vilnius, JDC9005)

Syninclusions. None.

DESCRIPTION. Male. Light to dark brown; elytra black (Figs 1-4).

Head transverse, noticeably narrowed posteriorly, with very short cheeks. Eyes relatively small, eye diameter ca. 3 times greater than head width behind eyes. Mandibles slender, relatively long, evenly rounded. Palps slender, ultimate palpomeres securiform, noticeably wider than penultimate palpomeres. Antennae 11-segmented, filiform, narrow, extending to elytral half, with antennomere $3 \mathrm{ca} .2 .9$ times longer than pedicel (antennomere 2) and ca 1.2 times shorter than antennomere 4; antennal pubescence relatively short and suberect.

Pronotum subquadrate, with semicircularly produced forward anterior margin, slightly concave sides and noticeable rounded anterior and short posterior angles; disc smooth, with two prominent basal swellings. Scutellum triangular, rounded at apex (Figs 1-4)

Elytra elongate, narrow, ca. 3 times longer than wide, parallel-sided, shining and coarsely punctuate, with uniform suberect pubescence (Figs 1-4).
Legs long, with robust femora and narrow tibiae, and tibiae slightly longer than femora; hind tarsomere ratio: 4 : $2.2: 1.8: 1: 1.6$; tibiae with dense erect vestiture and distinct long spurs; tarsomere 4 conspicuously widened and split almost to base; claws simple (Figs 1-4).

Abdomen fully covered by elytra, with eight visible sternites; ultimate tergite triangularly incised distally; penultimate ventrite broad, medially semicircularly incised, ultimate ventrite oval, narrowing distally and minutely incised at apex (Fig. 2).

Length (from anterior head margin to end of elytra): 12.0 $\mathrm{mm}$; width (at humeri): $3.6 \mathrm{~mm}$. (Figs 1-2).

Female. Unknown.

ETYMOLOGY. The name of the new species is derived from the Latin for 'coarsely punctate', alluding to its elytral punctuation.

DIAGNOSIS. Lycocerus crassepunctatus sp.n., would key to L. jonasi Kazantsev, 2020 in the determination key to Baltic amber Lycocerus species [Kazantsev, 2020], but is easily separable from it, as well as from other Baltic amber Lycocerus, by the coarse and dense punctuation of the elytra (Figs 1, 3).

REMARKS. The inclusion is well preserved in a relatively large, $23 \times 11 \times 7 \mathrm{~mm}$, and clear amber piece; however, its location in the piece does not allow observing it at a right angle from below.
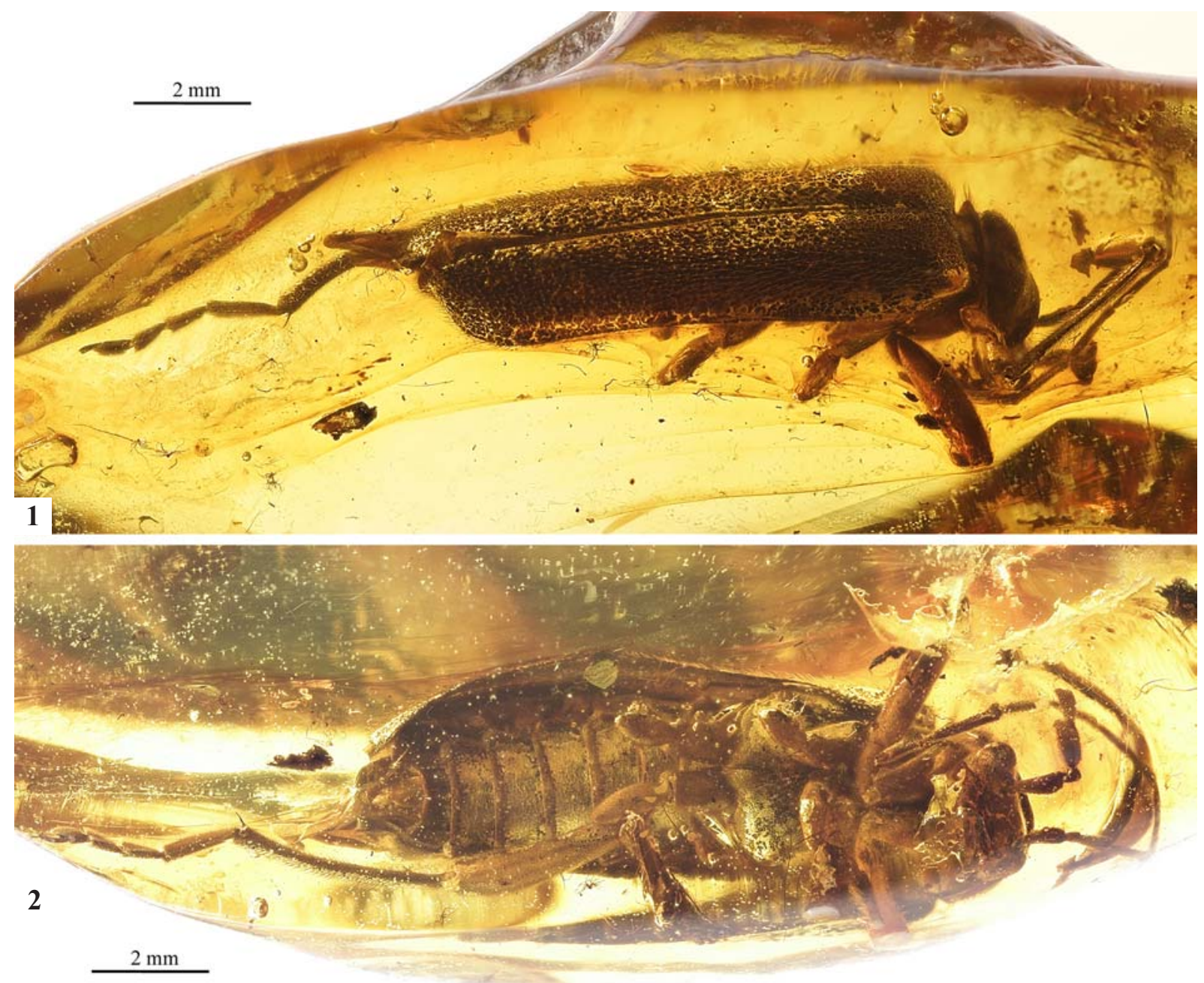

Figs 1-2. General view of Lycocerus crassepunctatus sp.n., holotype male: 1 - dorsal view; 2 - ventral view.

Рис. 1-2. Общий вид Lycocerus crassepunctatus sp.n., голотип, самец: 1 - сверху; 2 - снизу. 

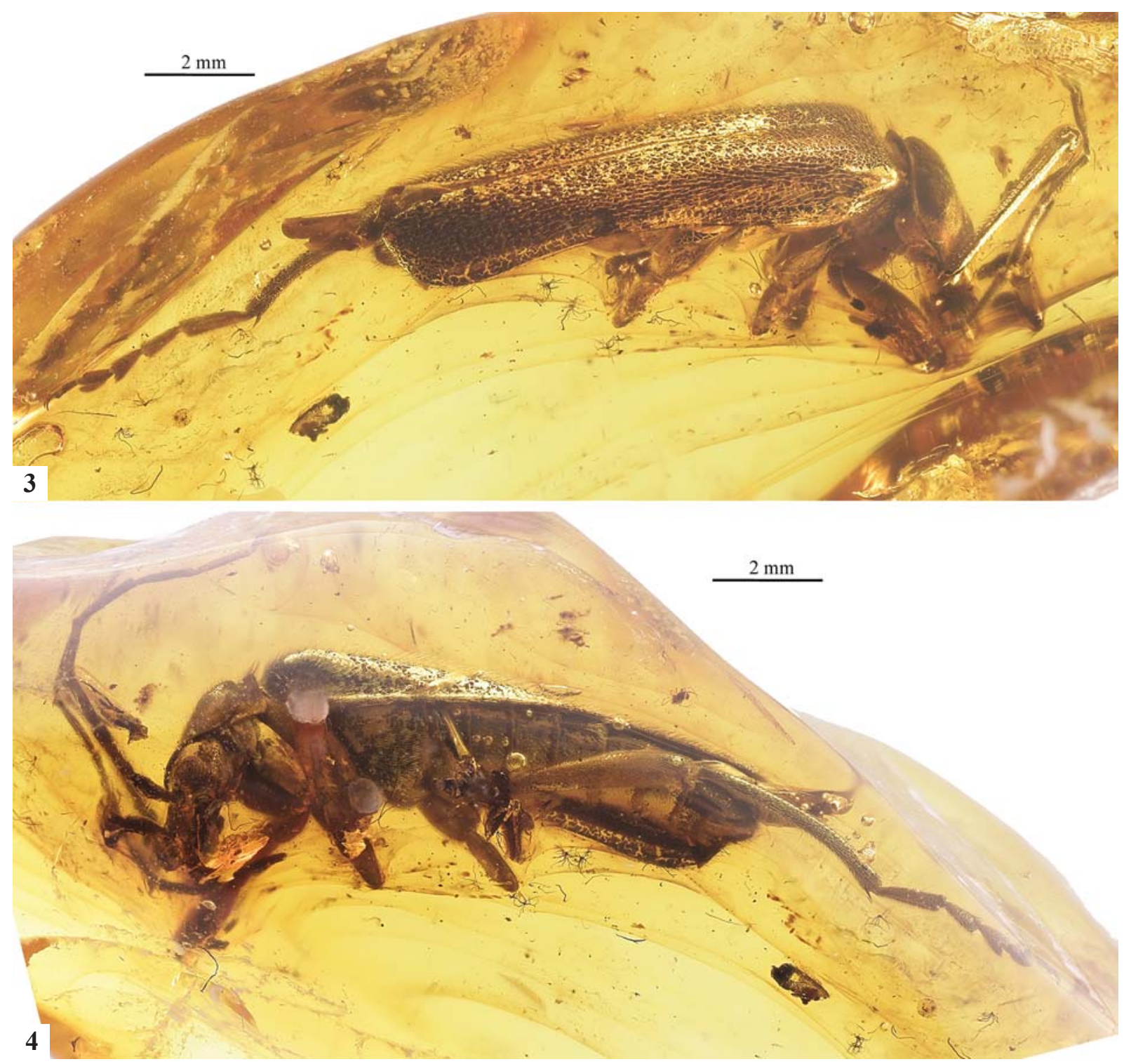

Figs 3-4. General view of Lycocerus crassepunctatus sp.n., holotype male: 3 - lateral view from the right; 4 - lateral view from the left. Рис. 3-4. Общий вид Lycocerus crassepunctatus sp.n., голотип, самец: 3 - сбоку справа; 4 - сбоку слева.

Malthininae Kiesenwetter, 1852

Malthodini Boving et Craighead, 1930

Malthodes Kiesenwetter, 1852

Type species: Malthinus marginatis Latreille, 1806, subsequent designation by Brancucci, 1980

\section{Malthodes aliger Kazantsev sp.n. Figs 5-10.}

MATERIAL: Holotype, $0^{7}$, specimen No. MAIG 6670, Baltic amber, Middle Eocene, Gdansk Gulf Baltic amber (Kaliningrad Oblast, Russia) (ex. coll. Jonas Damzen, Vilnius, JDC9136).

Syninclusions. None.

DESCRIPTION. Male. Dark brown to black; palps, antennae, pronotal sides, elytra and tarsi light brown; narrow pronotal margins light brown testaceous (Figs 5-6).
Head noticeably narrowed behind eyes. Eyes relatively large, interocular dorsal distance ca. 2 times greater than eye diameter. Terminal palpomeres elongate, noticeably larger than preceding ones, distally pointed. Antennae filiform, attaining to elytral half, with antennomere 3 ca. 1.4 times longer than pedicel (antennomere 2) and ca 1.1 times shorter than antennomere 4 ; antennomere ratio: $1.5: 1: 1.4: 1.5: 1.5$ $: 1.45: 1.4: 1.4: 1.3: 1.2: 1.5$; pubescence erect, relatively long, with longer separate bristles (Figs 5-7).

Pronotum subquadrate, almost straight at sides, margined throughout, with almost straight sides, slightly convex at anterior and posterior margins, with almost straight anterior and posterior angles (Figs 5-7). Scutellum triangular, rounded at apex.

Elytra elongate, not shortened, covering almost all the abdomen, almost parallel-sided, separately rounded at apices, with longitudinal rows of small punctures (Figs 5-6). 

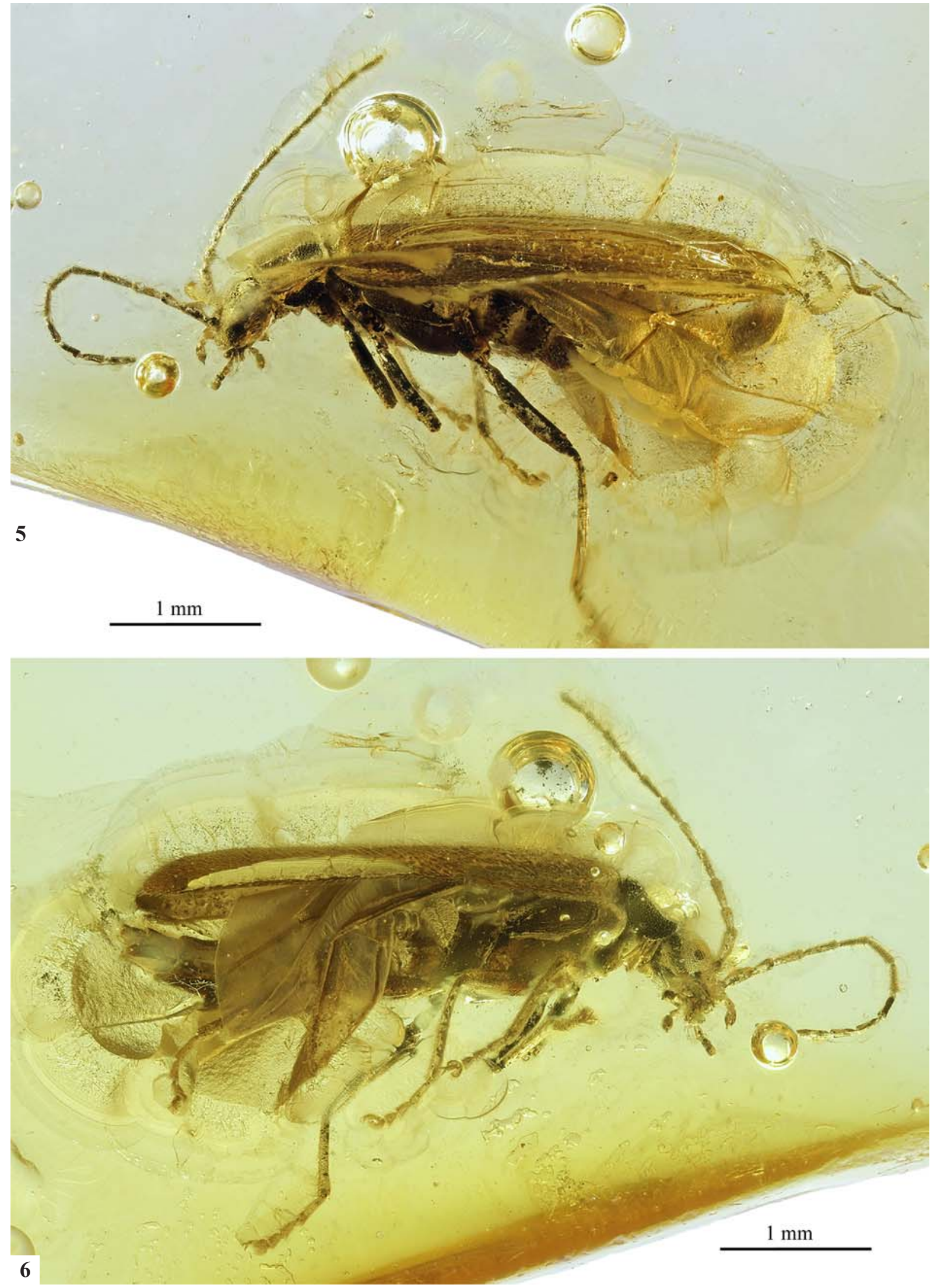

Figs 5-6. General view of Malthodes aliger sp.n., holotype male: 5 - lateral view from the left; 6 - lateral view from the right. Рис. 5-6. Общий вид Malthodes aliger sp.n., голотип, самец: 5 - сбоку слева; 6 - сбоку справа. 

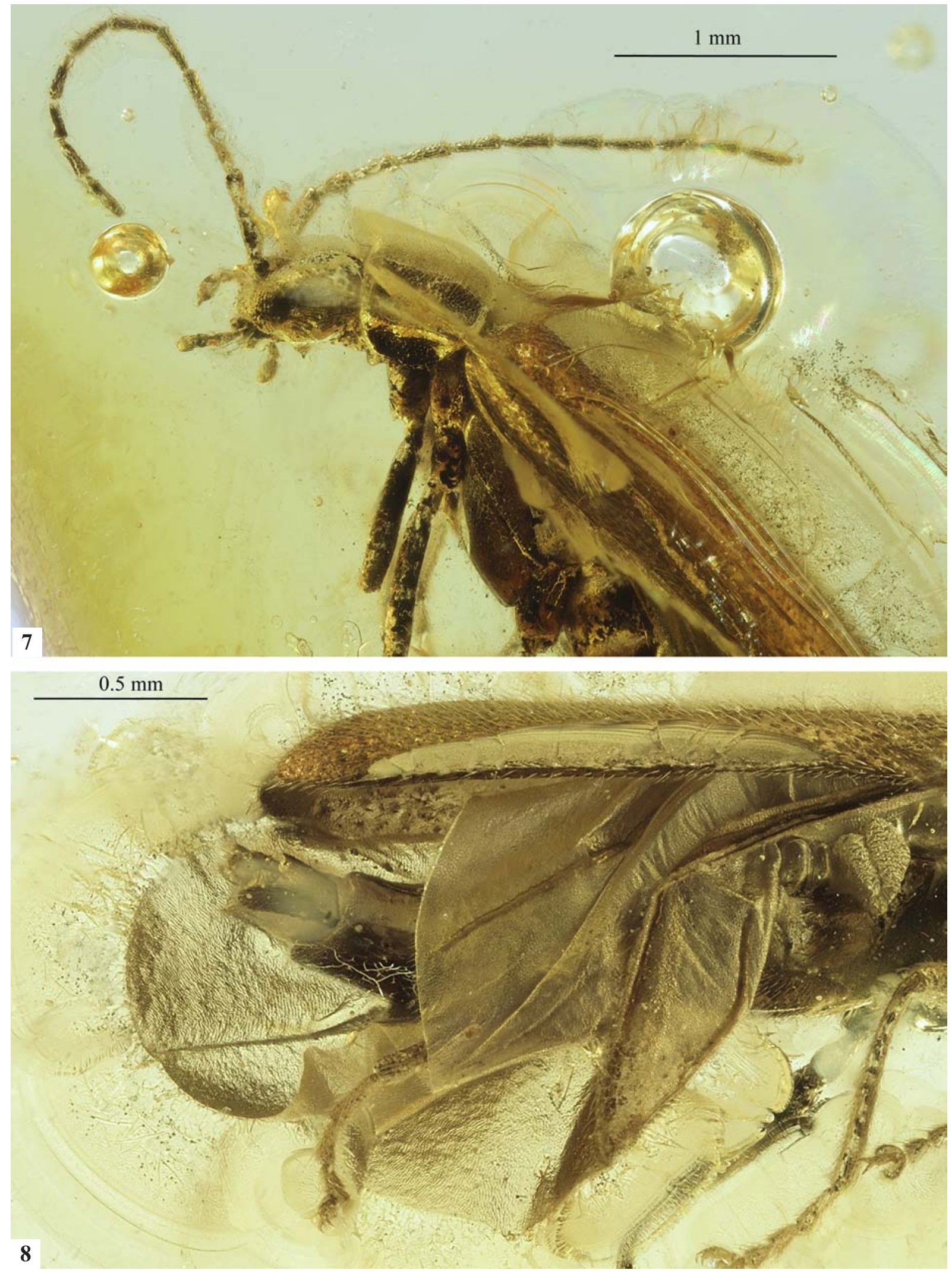

Figs 7-8. Details of Malthodes aliger sp.n., holotype male: 7 - anterior half of the body, lateral view from the left; 8 - posterior half of the body, lateral view from the right.

Рис. 7-8. Детали Malthodes aliger sp.n., голотип, самец: 7 - передняя половина тела, сбоку слева; 8 - задняя половина тела, сбоку справа. 

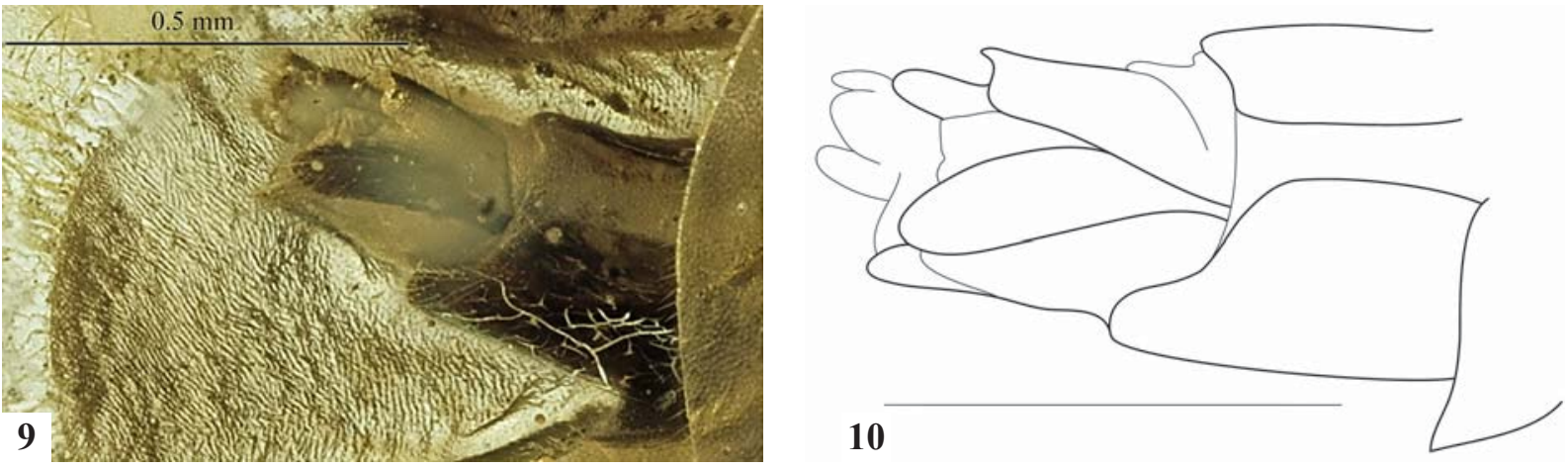

Fig. 9-10. Terminal abdominal segments of Malthodes aliger sp.n., holotype male, ventro-lateral view. Scale bars: 0.5 mm.

Рис. 9-10. Вершинные сегменты брюшка Malthodes aliger sp.n., голотип, самец, вид снизу и сбоку. Масштабные линейки: 0.5 мм.

Legs slender and long, femurs and tibiae straight, tibiae and femurs subequal in length; tarsomeres 1-3 narrow, tarsomere 4 conspicuously widened and incised to base (Figs 5 6,8 ); hind tarsus claw with distinct tooth at base (Fig. 8).

Terminalia with produced medially ultimate ventrite, with long, almost straight, slightly widened distally lateral lobes, and unmodified ultimate tergites, ultimate tergite ca. 0.5 times shorter than penultimate (Figs 8, 10).

Length (from anterior head margin to end of abdomen): ca. $4.3 \mathrm{~mm}$. Width (humeral): ca. $1.0 \mathrm{~mm}$.

Female. Unknown.

ETYMOLOGY. The name of the new species is derived from the Latin for 'winged', alluding to its developed hind wings and the length of its elytra.

DIAGNOSIS. Malthodes aliger sp.n. is quite unlike all amber congeners and, being somewhat similar to the extant M. spretus Kiesenwetter, 1852 in the structure of the terminalia, is easily separable by the long, almost straight, slightly widened distally lateral lobes of the produced medially ultimate ventrite and unmodified ultimate tergites (Figs 8, 10). Another character of the new species, a tooth at the base of hind claws (Fig. 8), has not been previously reported in Malthodes.

REMARKS. The inclusion is preserved in a relatively large, but thin, $17 \times 14 \times 2 \mathrm{~mm}$, and clear amber piece; however, its location in the piece prevents observing it at a right angle from above and below.

Acknowledgements. It is my pleasant duty to express gratitude to Dr. El bieta Sontag (Museum of Amber Inclusions, Gdañsk, Poland) for the possibility to study the Baltic amber inclusions under her care and to Mr. Aleksej Damzen (Vilnius, Lithuania) for the photos of the new taxa.

\section{References}

Delkeskamp K. 1977. Pars 165. Fasc.1: Cantharidae // Coleopterorum Catalogus Supplementa. Editio secunda. The Hague: W. Junk Publishers. 485 pp.

Gaigalas A., Halas S. 2009. Stable isotopes (H, C, S) and the origin of Baltic amber // Geochronometria. Vol.33. P.33-36. https:// doi.org/10.2478/v10003-009-0001-9

Helm O. 1896. Beiträge zur Kenntnis der Insekten des Bernstein // Schriften der Naturforschenden Gesellschaft in Danzig N.F. B.9. H.1. S. $220-231$.

Kazantsev S.V. 2020. New Baltic amber soldier beetles (Insecta: Coleoptera: Cantharidae) with some taxonomic notes // Palaeoentomology. Vol.003. No.3. P.260-268. https://doi.org/ 10.11646/palaeoentomology.3.3.7

Kazantsev S.V., Brancucci M. 2007. Cantharidae // Löbl I., Smetana A. (eds.). Catalogue of Palaearctic Coleoptera. Vol.4. Stenstrup: Apollo Books. P.234-298.

Klebs R. 1910. Über Bernstein einschlösse im allgemeinen und die Coleopteren meiner Bernsteinsammlung // Schriften der Physikalisch-ökonomischen Gesellschaft zu Königsberg. Bd.51. H.3. S.217-242.

Parisi F., Fanti F. 2020. Baltic amber: A new Cacomorphocerus Schaufuss, 1892 with two specimens preserved in a single piece, and four new Malthodes Kiesenwetter, 1852//Zootaxa. Vol.4778. No.3. P.546-560. https://doi.org/10.11646/zootaxa.4778.3.6

Schaufuss C. 1892. Preussens Bernstein-Käfer. I. Neue Formen aus der Helm'schen Sammlung im Danziger Provinzialmuseum // Berliner Entomologische Zeitschrift (1891). Bd.36. H.1. S.5364.

Yablokov-Khnzoryan S.M. 1960. [New beetles from the Baltic amber] // Paleontologicheskij Zhurnal. Vol.3. P.90-101 [in Russian].

Zang R. 1905. Coleoptera Longicornia aus der Berendtschen Bernsteinsammlung // Sitzungs-Berichte der Gesellschaft Naturforschender Freunde zu Berlin 1905. S.232-245. 